\title{
Construction on Curriculum Group for British and American Literature
}

\author{
Yan Liu \\ Teaching and Research Institute of Foreign Languages, Bohai University, Jinzhou, 121013, China \\ 2439989361@qq.com
}

Keywords: British and American literature; curriculum group; construction; principle

\begin{abstract}
British and American literature course group construction from its own characteristics, grasp the knowledge chain link between British and American literature and other subjects, and considering factors in aspects of curriculum content and curriculum theory knowledge, construct a reasonable group of British and American literature course. This paper follow the relevance, independence and diversity of curriculum group construction, systematic and harmonious unity and sustainable development principle, build a group of British and American literature class, mainly includes many curriculum that are "British and American short stories, English literary classics reading, American literary classics reading, British and American children literature, American classical literature, Modern and contemporary literature of the United States, English classical literature, Selected reading in English theatre, British and American literature appreciation, Selected reading in English poetry, Selected reading in English essays, Modern and contemporary literature of the English" et al.
\end{abstract}

\section{Introduction}

Curriculum group is a modern education thought and theory as the instruction, around the same or different professional talent training goals and objectives, to perfect relevant professional students' knowledge, ability and quality structure, the corresponding professional knowledge, methods and problems in the training scheme of the logical link is a number of courses, reorganize and integrate built an organic curriculum system [1]. To carry out the curriculum group construction is beneficial to the optimal allocation of teaching resources, make the content of the curriculum group of more comprehensive, but also broke the belonging of the course content, enhances the convergence between different courses [2]. Construction of curriculum group is development trend of the reform of curriculum construction in recent years. On the one hand, because of the country's "teaching contents and curriculum system reform facing the 21st century", promote the whole optimization of school curriculum integration; on the other hand, along with the reform of university curriculum management, teaching staff, management reform, and the optimal allocation of teaching resources, curriculum construction began to pay attention to the construction of the radiation effect and scale effect. Curriculum group is a self-organizing system, according to the dissipative structure theory, can open system in a certain external conditions, through internal interaction to generate organizational and coherence, emphasized the connection between all the elements within the system and the coupling, therefore, system evolution path, direction and structure and diversity. Curriculum group is such an open and a self-organizing system, and on the basis of human development, optimizing the allocation of curriculum resources, and give the course subject full of options, the course group for people, because of time and from place to place and show the different development situation, realize the diversification of curriculum and flexibility.

After grade three English major students to enter university, learn English country profiles, English literature, American literature, in accordance with the outline of the fourth grade can take courses related to English and American literature and culture. For future students to engage in the study of English and American literature, guiding them to appreciate literary works effectively, and expand the relevant literature criticism. But due to the lack of teachers, the subsequent spread of poetry, prose, fiction and drama vast course open optional sex is stronger, and the previous course, lack of organic connection among curriculum is putting the cart before the horse. English country profiles, for example, with the British society and culture, the American society and culture the two 
courses should present progressive relationship, but because there is no communication between the teacher and artificially cause strain on repetition of teaching content and teaching hours, students can't have more in the limited time, deeper and wider knowledge, nature also will lose learning interest and enthusiasm. Thus, in the current curriculum and teaching mode, although British and American literature and culture course gate number is numerous, but the teaching effect is not very desirable, a course for another course couldn't reflect the mean, single course loose construction is weak, and the construction of British and American literature course as the core, in the base class and develop related courses for auxiliary "curriculum group of British and American literature and culture", the necessity of more and more highlighted. In the process of practical teaching plan formulation, according to the school, professional and the specific situation of the teachers, the curriculum group of related courses for appropriate trade-off or merged, so conducive to the students' interest in professional development and the characteristics of talent cultivation, beneficial to the improvement of the cross-cultural communication ability, realize optimization of integrated resources, improve teaching efficiency.

\section{Principles of Curriculum Group Construction}

Curriculum group is influence each other in the teaching plan, closely connected, interactive and orderly related courses, to design and integrate build a collection of courses, generally from belongs to a certain disciplines, with the teaching requirements of the overall, has the modular teaching content, between each course in the group can better embody the organic permeability and integrated, is beneficial to giving full play to the advantages of group. Curriculum group constructions are strong academic and have stronger practical operability. In the construction of curriculum groupshould pay attention to the following principle [3, 4]:

(1) The principle of relevance. On the content of curriculum group is composed by mutual penetration and integration, and form an organic whole of related courses. Content longitudinal have inheritance relationship, transverse has inner link, but sui generis. Curriculum group construction, therefore, to be in accordance with the requirements of talents training target and training mode, analysis on the logical structure of relationship between curriculum, break the barriers between courses, optimizing curriculum system, integration of teaching contents and teaching methods, fully considering the course in the same group in structure, content and teaching time allocation relationship.

(2) The principle of independence. Independence includes two aspects: the curriculum structure, and refers to the independence, between the group and the group reflects the overall structure of the discipline curriculum; of course group of itself, is refers to the group of mutual independence between the courses. According to the talent cultivation objectives and specifications, from the aspects of course system and course structure for the overall design and discussed, from the aspects of curriculum structure and the optimization of teaching system for curriculum construction, pay attention to the science curriculum, makes every effort to reduce the content of the course, compression unnecessary class, optimize the course structure and teaching system, and has the relative independence between the courses.

(3) The principle of diversity. Higher education should cultivate diverse talents, should not be like the products of the production line. Education should be to respect and develop one's personality, make each student get free comprehensive development. The existing education plan is of universal significance to construct, for interest, hobby and specialty of different students, there is no fundamental solution. Curriculum group construction group the collective wisdom of teacher, and in order to cultivate and development specialty students. Curriculum group construction and practice must be based on principles of diversity, multi-level meet students' needs, making different students' personality development.

(4) The system principle. System is composed of mutual connection and interaction of a number of elements, is the organic whole with a specific function, system and elements by contacting each other. Curriculum group construction must follow the principle of system theory, from the perspective of the relationship between system and element, fully considering the curriculum group 
and the relationship between the whole course system and teaching system, curriculum group and a specific course of the curriculum group, the relationship among the curriculum group construction cannot be isolated. Neither blindly expand nor change course group of position in the whole course system structure, and can't and the pursuit of a specific course of completeness.

(5) The coordination principle of unity. Traditional courses in general shall be the responsibility of the backbone teachers, but the curriculum group, to break the fragmented situation, need to participate the teacher to do their job, try my best to do due diligence. To adjust course content, merge and rejecting, adjust class number, also unified deployment for equipment and funds. Every teacher should coordinate analysis was carried out on the content and system reform on a regular basis, promoting the construction of curriculum group together. Teachers on a regular basis to carry out the theme of seminars, related problems on the curriculum group construction of communication and coordination.

(6) The principle of continuous development. Curriculum group construction is a complicated system engineering one of teaching reform, wide range, long construction period, large workload. Remarkable achievements were obtained in the short term it is difficult to, must be constant attention, reasonable arrangement. The teacher wants to clear construction objectives and tasks, focused, advance step by step, to avoid the blindness and disorder. Well prepared for the construction of long-term, mid-term and long-term programs and annual plans, and constantly improve the quality of teachers, formulate the corresponding safeguard measures and incentive measures to ensure the sustained, steady and orderly and the development of.

\section{British and American Literature Curriculum Group Construction}

According to the ministry of education promulgated the "high school English professional English syllabus", the professional knowledge of English courses related to English and American literature and culture in the course have ten different departments. Professional knowledge including English literature, American literature is a compulsory course and English country profiles, etc.; Professional knowledge courses including the British society and culture, the social and cultural, selected readings in English novels and English prose selections, selected readings in English drama, selected readings in English poetry, etc. These courses is an important course of college English major education stage, is also indispensable to cultivate and improve students' humanities accomplishment core curriculum, course between, is mutually independent and mutual penetration. But in actual teaching process, each class the teacher basically fragmented, mutual communication, of course undertake what kind of role in the whole course system, has the don't care about such as how to link with other courses, teachers' teaching ideas narrow, difficult point is not prominent, content repetition, lack of breadth and depth, causing students cognitive structure is imperfect. To solve these problems of the construction of the curriculum group is shown in Fig.1.

\begin{tabular}{|c|c|}
\multicolumn{2}{c}{ Curriculum group for British and American literature } \\
\hline British and American short stories & English classical literature \\
\hline English literary classics reading & Selected reading in English theatre \\
\hline American literary classics reading & Selected reading in English poetry \\
\hline British and American children's literature & Selected reading in English essays \\
\hline American classical literature & $\begin{array}{c}\text { Modern and contemporary literature of the } \\
\text { English }\end{array}$ \\
\hline
\end{tabular}

Fig. 1. Composition on Curriculum group for British and American literature

For the part as shown in Fig.1, brief description is as follows: 
(1) British and American short stories[5]. Students taking this course will read thirty-odd short stories, most of which were written by British and American writers in the 20th century. In order to enhance their ability in appreciating the short story as a separate genre of fictional writing and critically analyzing it, Shlomith Rimmon-Kenan's Narrative Fiction: Contemporary Poetics will also be covered one chapter after another in class, usually in the second class period. By the end of the course, students are expected to be able to provide brief definitions for some of the most important narratological terms explained in the book, a list of which will be given towards the end of the semester. Besides, throughout the course, each student will be given a chance to make at least one presentation on the materials from either the main text or Supplementary Readings. This requirement is intended not only to increase our students' amount of reading but also to give them an opportunity to present in class their relevant critical ability.

(2) American classical literature. By analyzing summarizing American literature, let the students understand the development situation of the American literature, familiar with the main writer; Through reading appreciation main stages novels, poems, and representative works of various genres of drama, introduce the basic knowledge and method of literary criticism, enhance students' knowledge of American literature and culture, promote the students' language basic skill and the improvement of literature appreciation, cultivate the students' independent thinking ability, improve the level of the students' literary criticism. Students are required to understand exactly works, read through the original classic requirement, can work published their own views and issues related to able to write articles of literature theory. In addition to lectures, classroom teaching will give students space to arouse the enthusiasm of students, in class discussions.

(3) English classical literature in English history as the main line, combining with the literature of a period of major ideological trend, to teach English literature major writers and works. Through the history of British literature writer main work background of carding and major works of teaching, on the one hand, promote students the accumulated knowledge of western culture and to a better understanding of the western humanism thought; On the other hand, through to the classics reading, lecture and discussion, to improve student's perceptions of the English language proficiency and the accumulation of written language of English, through the study of literary works to improve students' English reading, writing and text analysis ability, that is, language application ability and logical thinking ability. In addition, through class show, class discussion and group work outside links, improve the students' unity cooperation ability. Through the guidance of lectures and activities of each links and promote students' aesthetic accomplishment and humane accomplishment.

(4) British and American literature appreciation, so that the students on the formation and development of American literature overview of context; And through reading and understanding the representative work, the focus of the master the basic knowledge of literature, learn the art of analyzing the characteristics, improve the level of the students' literary appreciation and literary criticism; Combined with language teaching, through the literature to improve students' sensitivity to the culture and language application level, improve the students' humanistic quality. Through the course content, discussion, research and student's work, consciously cultivate students' thinking ability, research ability and oral English and writing ability; The students to learn and grasp of the English language, and further improve the comprehensive language ability, make its basic knowledge and theory knowledge of English language have more systematic control. Understand important writer's literary career, creative thinking, artistic features, and its representative works of thematic structure, characterization and language style, thinking, etc., to further understand the work, understand their ideological content and writing characteristics, improving the ability of read and appreciate literature.

(5) Selected reading in English essays. Collect different historical period of the famous western writer, scholar's masterpiece, the full text, and extracts the content involved in literature, art, history, social, religious and daily life, many aspects, such as student observation from its ideas of western civilization, in the study of the philosophical speech, intriguing paradox and thought-provoking epigram, thinking and feeling my life. Peruse the sending out the rich western culture but there is no 
lack of insight, full of personality even masters, make English students to gain great satisfaction in spirit, to strengthen their ability to abstract thought, appreciate the art style of English prose glows, and deeply understand English words glittering rich expressive force.

\section{Conclusion}

The talents training goal of institutions of higher learning for English majors is to cultivate with solid English language foundation and broad interdisciplinary talents and cultural knowledge. In addition to offering English professional skills courses, also English professional knowledge courses, including literature and social culture. British and American literature course group construction from its own characteristics, grasp the knowledge chain link between British and American literature and other subjects, and considering factors in aspects of curriculum content and curriculum theory knowledge, construct reasonable English and American literature course group of [6]. Actual construction should follow the following strategies: when integrating courses related to English and American literature, the formation of British and American literature centered, reasonable curriculum group; Integrated courses related to teachers, form and selected readings in British and American literature teacher centered teaching team; To reform the traditional classroom teaching, improve teaching methods and means, perfect the teaching content; Reforms the inspection way, the establishment of formative assessment and summative assessment and the new evaluation model.

\section{References}

[1] H. H. Guo, "The Study of Current Situation and Countermeasures of College Network Curriculum group construction," Master's degree of Henan University, 2012.

[2] C. Y. Long, "Course group construction: the path choice of the teaching reform in Higher Education," Modern Education Science, vol. 4, no. 2, pp. 139-141, 2010.

[3] L. P. Zhang, D. S. Liu, M. Liu, "The construction and practice of the teaching management system of course group," Journal of Inner Mongolia Normal University (Educational Science), vol. 26, no. 3, pp. 61-64, 2013.

[4] C. X. Yun, Y. H. Qin, "Study on the Resource Optimization and Personnel Training as Curriculum Group the Core," Science and Management, vol. 32, no. 2, pp. 87-92, 2012.

[5] Fudan University, "British and American short stories," http://jpkc.fudan.edu.cn/s/292/t/607/p/1/c/7834/list.htm, 2016-6-30.

[6] F. Wang, J. T. Zeng, "The construction of the excellent course group of British and American literature from the perspective of the co students," Journal of Language and Literature Studies, vol. 30, no. 10, pp. 134-136, 2010. 